\title{
Yüksek tibial osteotomi eksternal fiksatörü
}

\author{
High tibial osteotomy external fixator
}

\author{
Melih Güven \\ Ataşehir Florence Nightingale Hastanesi, Ortopedi ve Travmatoloji Kliniği, İstanbul
}

Buluş, yüksek tibial osteotomi (YTO) cerrahisinde kullanılan fiksatörler ile ilgili olup, özelliği; bacağı her iki taraftan kavrayan en az bir hizalayıcı, hizalayıcı ile irtibatlanan en az bir açılanabilir bağlantı parçası ve proksimal ark, proksimal ark üzerinde en az bir proksimal shanz tutucu, açılanabilir bağlantı parçasının alt kısmında en az bir distal shanz tutucu, proksimal ark üzerine yerleştirilip cilt üzerinde açılacak kesinin konumunu ve boyutunu ayarlamayı sağlayan en az bir kesi bloğu, açılanabilir bağlantı parçası ile irtibatlı en az bir fibula başı hizalayıcı aparat, düzeltme açısının ayarlanıp kontrol edildiği en az bir açısal gösterge içeren yüksek tibial osteotomi (YTO) eksternal fiksatörü ile karakterize edilir.

Anahtar sözcükler: yüksek tibial osteotomi; fiksatör; osteotomi; düzeltme

\section{T. C. Türk Patent Enstitüsü'ne Faydalı Model Belgesi için Başvuru Bilgileri ${ }^{[1]}$}

Başvuru bilgileri Tablo 1'de gösterilmiştir. ${ }^{[1]}$

Tablo 1. Başvuru bilgileri ${ }^{[1]}$

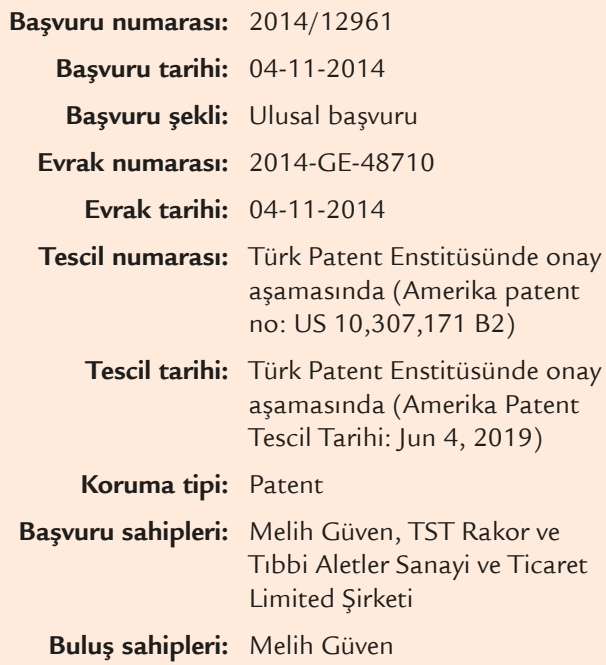

Tescil tarihi: Türk Patent Enstitüsünde onay aşamasında (Amerika Patent Tescil Tarihi: Jun 4, 2019)

Koruma tipi: Patent

Başvuru sahipleri: Melih Güven, TST Rakor ve Tıbbi Aletler Sanayi ve Ticaret Limited Şirketi

Buluş sahipleri: Melih Güven

The invention is related with an external fixator that is used in high tibial osteotomy (HTO) surgeries, including at least one positioner for gripping the leg from both sides, at least one angulation device and a proximal arch that is connected to the positioner, at least one proximal schanz holder on the proximal arch, at least one distal schanz holder at the bottom of the angulation device, at least one osteotomy block that enables to set the size and location of the incision on the proximal arch, at least one fibular head positioning device that is connected to the angulation device and at least one angular indicator (scale) on the fixator, on which the correction can be adjusted and controlled.

Key words: high tibial osteotomy; fixator; osteotomy; correction
PATENT BAŞVURU BELGESI - No: $2014 / 12961^{[1]}$
UNITED STATES PATENT NO: US 10,307,171 B2 ${ }^{[2]}$

\section{Teknik Alan ${ }^{[1]}$}

“Mevcut buluş; yüksek tibial osteotomi (YTO) cerrahisinde kullanılan fiksatörler ile ilgilidir.

Buluşözellikle, YTO cerrahisinde daha kısa sürede iyileșme sağlayan, operatörün işini kolaylaştıran yeni bir YTO eksternal fiksatörü (YTO dıştan tespit sistemi) ile ilgilidir."

\section{Önceki Teknik/Teknikler ${ }^{[1]}$}

"Alt ekstremite mekanik aks diziliminin varus pozisyonunda (diz ekleminin medialinde) yer alması, diz ekleminde medial eklem aralığının daralmasına ve gonartroz (kireçlenme) gelişiminin hızlanmasına neden olan bir patolojidir. ${ }^{[3]}$

Tibia proksimalinden (üst ucundan) uygulanan YTO girişimi mekanik aksın nötral pozisyonda (nötral dizilim: alt ekstremite mekanik aksının diz ekleminin tam ortası ya da en fazla $8 \mathrm{~mm}$ medialinden geçmesi) dizilimini gerçekleştirerek gonartroz (kireçlenme) gelişim sürecini durdurur ya da yavaşlatır. ${ }^{[4-6]}$

- İletişim adresi: Prof. Dr. Melih Güven, Ataşehir Florence Nightingale Hastanesi, Ortopedi ve Travmatoloji Kliniği, Küçükbakkalköy, Işıklar cad., No: 35/A, 34750 Ataşehir, İstanbul Tel: 0505 - 3737416 e-posta: maguven2000@gmail.com ORCID iD: 0000-0002-9656-1608

- Geliș tarihi: 5 Kasım $2020 \quad$ Kabul tarihi: 21 Kasım 2020 
YTO girişimleri lateralden kapalı kama, medialden açık kama ya da dome (sferik) osteotomileri ile gerçekleştirilebilir. Tüm bu osteotomi seçeneklerine yönelik değisisik implantlar (plak, U çivileri, sirküler ya da uniplaner fiksatörler v. b.) kullanılmaktadır. ${ }^{[7-9]}$

Açık cerrahilerde gerek lateral, gerekse medialden gerçekleştirilen uygulamalar sonrası enfeksiyon, kaynamama gibi problemlerin yanı sıra kullanılan tespit materyalinin sağladığı stabiliteyle de ilgili bir takım sıkıntılar yaşanabilmektedir. ${ }^{[10,11]}$

Osteotomi işlemi sırasında zaman zaman karşı korteksin kırılması sonucu korreksiyon (elde edilen açısal düzeltme) kaybı görülebilmekte, stabil olmayan tespit uygulamaları sonrası hastaya yük verdirilememekte ve dolayısıyla da hastanın rehabilitasyon süreci uzamaktadır. ${ }^{[12-14]}$

Bu durumda hastanın ayağa kalkma süresi uzamaktadır. Büyük cerrahi kesilerden yapılan operasyonlarda, kesinin büyüklüğü sebebiyle enfeksiyon meydana gelebilmektedir. Bu tür olumsuzlukları gideren ve hastanın daha kısa sürede ayağa kalkmasını sağlayan bir çözüme ihtiyaç duyulmaktadır.”

\section{Buluşun Kısa Tarifi ${ }^{[1]}$}

"Tekniğin bilinen durumundan yola çıkılarak buluşun gayesi, cerrahi girişime ilişkin yukarıda bahsedilen olumsuzlukların ortadan kaldırılmasına yönelik YTO eksternal fiksatörü (YTO dıştan tespit sistemi) geliştirilmesidir.

Buluşun amaçlari;

- Medialden uygulanan açık kama tibial osteotomisi için geliştirilen YTO eksternal fiksatörü ile ameliyat içerisinde fiksatör üzerinden tedrici düzeltme yapılabilmesi, hastanın ameliyat sonrası ertesi gün tam yük verdirilerek mobilize edilmesi, gerektiğinde ameliyat sonrası erken dönemde düzeltme miktarının değiştirilebilmesi gibi önemli avantajların elde edilmesidir.

- Sistemin tibiaya kolay tespiti ile ameliyat süresini azaltmaktır.

- Plak ve çivi uygulamalarından farklı olarak fiksatör sisteminin tespitinin ardından osteotomi (kemiği kesme) işlemini yapmaktır.

- 3-4 cm'lik bir cilt insizyonu ile geniş yumuşak doku diseksiyonu yapmaksızın osteotomi uygulamasını gerçekleştirerek cerrahi insizyonu küçültmek ve ilişkili cilt sorunlarının önüne geçebilmektir.

- Osteotomi sırasında ve sonrasında, osteotomi hattında tedrici ve kontrollü distraksiyon (kemiği kesme işleminin ardından açısal düzeltme amacı ile yapılan açma işlemi) yapabilmektir.

- Osteotomi hattında kontrolsüz kırılmaları (osteotomi hattının lateral kortekse ya da tibia platosuna uzanması) engellemek; kırılma gerçekleşse bile sistemin stabilitesi nedeniyle erken yüklenmeye izin vermektir.

- Osteotomi hattında kaynama elde edildikten sonra ikinci bir cerrahi girişime ihtiyaç duymaksızın sistemi çıkartmaktır. Özellikle plak uygulamalarında ikinci bir cerrahi girişim ile implant çıkarılabilmekte iken, buluş sayesinde poliklinik şartlarında ya da ameliyathanede anestezi uygulanmaksızın fiksatör çıkarılabilmektedir.

- YTO girişiminden sonra gerçekleşebilecek diz protezi cerrahisinde açık cerrahilerde yaşanabilecek cilt insizyonu ile ilgili sıkıntıların önüne geçmektir. Standart plak uygulamalarında kullanılan cilt insizyonu ile daha sonra yapılması muhtemel olan diz protezi cilt insizyonu kesişebilmektedir. Fiksatör uygulamasında ise hem çok küçük bir insizyon kullanılmakta, hem de bu insizyon daha sonra uygulanacak diz cerrahilerine ait insizyonlara engel olmamaktadir.

Bahsedilen amaçlara ulaşmak üzere, hastaların daha kısa sürede iyileşmesini sağlayan ve cerrahi operasyonun başarı olasılı̆̆ını yükselten yeni bir YTO eksternal fiksatörü (YTO dıştan tespit sistemi) gelişsirilmiştir.”

\section{Buluşun Detaylı Açıklanması [1]}

"Referans numaraları: (1) Hizalayıcı, (2) Fibula başını hizalayıcı apparat, (3) Açılanabilir bağlantı parçası, (4) Distal shanz tutucu, (5) Kesi bloğu, (6) Teleskobik rod (distraktör), (7) Proksimal shanz tutucu, (8) Proksimal ark, (9) Fibula Kirschner teli yönlendirici vida, (10) Fibula Kirschner teli gövdesi, (11) Fibula Kirschner teli gövde bağlantı vidası, (12) Fibula Kirschner teli bağlantı parçası, (13) Fibula başı, (14) Kirschner teli, (15) Motorlu testere, (16) Manüel osteotom, (17) Otojen ve/veya allojen greft, (18) Shanz vidası, (19) Açısal gösterge (skala), (20) Menteşe noktası, (21) Shanz vidası yuvası, (22) Kirschner teli yuvası, (23) Kesi açıklığı (Kesi bloğu üzerindeki açıklık) (Şekil 1, Şekil 2 ve Şekil 3).

Bacağı her iki taraftan kavrayan en az bir hizalayıcı (1), hizalayıcı (1) ile irtibatlanan en az bir açılanabilir bağlantı parçası (3) ve/veya proksimal ark (8), proksimal ark (8) üzerinde en az bir proksimal shanz tutucu (7), açılanabilir bağlantı parçası (3) alt kısmında en az bir distal shanz tutucu (4), proksimal ark (8) üzerine monte, de-monte edilen, cilt üzerinde açlacak kesinin konumunu ve boyutunu ayarlamayı săglayan en az bir kesi bloğu (5), açılanabilir bağlantı parçası (3) ile irtibatı en az bir fibula başı hizalayıcı aparat (2), düzeltme açısının ayarlanıp kontrol edildiği en az bir açısal gösterge (19) içeren YTO eksternal fiksatörü oluşturulmuştur.

Proksimal ark (8) ile açılanabilir bağlantı parçası (3) arasında en az bir teleskobik rod (6) içerir. Proksimal shanz tutucu (7) ve distal shanz tutucu (4) üzerinde en az bir shanz vidası yuvası (21) oluşturulmuştur. Kesi bloğu (5) üzerinde, açılı konumda en az bir kesi açıklığı (23) ve/veya en az bir Kirschner teli yuvası (22) bulunur.

Açılanabilir bağlantı parçalarının (3) uç kısmında açısal düzeltme konumunun ayarlanmasını sağlayan en az bir menteşe noktası (20) içerir. 
YTO eksternal fiksatörünün çalışma şekli şu şekilde açıklanabilir:

Hasta supin (sırtüstü yatar) pozisyonda, radyolusent (Işın geçirgen) masa üzerinde, patella orta hatta iken skopi kontrolünde diz ekleminin radyografik görüntüleri alınır.

Hastanın kruris proksimal (bacağın üst kısmı, diz ekleminin hemen altı) çapına göre uygun büyüklükteki proksimal ark (8) ile YTO eksternal fiksatörü kurulur. Kurma işleminde açılanabilir bağlantı parçası (3), proksimal ark (8), proksimal shanz tutucu (7), distal shanz tutucu (4) ve teleskobik rod (6) parçaları kullanılır.

Hizalayıcılar (1) ile YTO eksternal fiksatörü anterior tibial krize (bacağın tam orta kısmına) ortalanır (Şekil 4).

Proksimal ark (8) tibia proksimal eklem yüzüne (diz eklem hattına) paralel halde tutulurken, YTO eksternal fiksatörü açılanabilir bağlantı parçaları (3) ucundaki menteşe noktasından (20) fibula başını hizalayıcı aparat (2) ile koronal (frontal ya da karşıdan bakar pozisyonda) planda fibula başına (13) iz düşümlenecek şekilde hizalanır. Bu hizalama için kullanılacak parça fibula başını hizalayıcı aparat (2); fibula Kirschner teli yönlendirici vida (9) ile irtibatIı fibula Kirschner teli gövdesi (10), fibula Kirschner teli gövde bağlantı vidası (11) ve fibula Kirschner teli bağlantı parçasından (12) oluşmaktadır (Şekil 5).

Proksimal ve distal shanz tutuculardan $(4,7)$ istenilen konfigürasyonda gönderilecek shanz vidaları (18) ile YTO eksternal fiksatörü tibiaya sabitlenir (Şekil 6).

Kesi bloğu (5), proksimal ark (8) üzerindeki yerine tespit edilir. Fibula başının (13) üst ucu hizalanacak şekilde kesi bloğu (5) üzerindeki deliklerden bir adet Kirschner teli (14) gönderilir ve telin aksı (yönelimi) skopi ile kontrol edilir (Şekil 7).

Uygun olduğu düşünüldükten sonra en az iki adet Kirschner teli (14) daha tibia proksimaline tespit edilir ve kesi bloğunun (5) proksimal ark (8) ile olan bağlantısı çıkartılır.

Kesi bloğu (5) Kirschner telleri (14) üzerinden cilde yaklaştırılır ve kesi bloğu (5) üzerinde motorlu testerenin (15) girdiği bölgeden cilt insizyonu yapılacak bölge belirlenir (Şekil 8).

Cilt-cilt altı kesilerinin ardından pes anserinus fasiası cilt kesisine paralel olacak şekilde açılır ve kemiğe ulaşılır.

Skopi kontrolünde kesi bloğu (5) üzerinden motorlu testere (15) yardımıyla osteotomiye başlanır. Lateral kortekse (kesi tibianın medialinden lateraline doğru devam ettirilir) $1 \mathrm{~cm}$ yaklaşıncaya kadar kesi devam ettirilir. Ardından kesi bloğu (5) ve Kirschner telleri (14) çıkartılarak osteotomiye anterior ve posterior korteksleri kesmek üzere manuel osteotomlar (16) ile devam edilir (Şekil 9 ve Şekil 10).

Osteotomi tamamlandıktan sonra menteşe noktasındaki (20) vidalar yardımıyla elde edilmek istenen düzeltme miktarı skalaya (19) bakılarak tedrici olarak yapılır. Istenirse teleskopik rod (6) da bu amaçla kullanılabilir.
Osteotomi hattında yeterli distraksiyon (açısal düzeltme) elde edildikten sonra sistem teleskopik rod (distraktör) (6) yardımıyla kilitlenir ve osteotomi hattı isteğe bağlı olarak otojen ve/veya allojen greft (17) ile doldurulur (Şekil 11).

YTO uygulamaları için bilimsel literatürde ${ }^{[4-6]}$ tarif edilmiş olan ve aşağıda sıralanmış gereklilikler YTO eksternal fiksatörü için de geçerlidir.

- Mekanik aksın varus pozisyonunda bozulmuş olduğu genu varum deformiteleri ve unikompartmantal gonartroz olguları (diz ekleminde enflamatuar artrit olan olgular haricinde)

- Menisektomi sonrası medial kompartmanın aşırı yük altında kalması

- Osteokondral defektlerde yüzey değisştirici artroplasti uygulamaları ile birlikte

- Diz eklem hareket genişliğinin $100^{\circ}$ 'nin üzerinde olması

- Medial ve lateral planda eklem laksitesi olmaması

- $15^{\circ}$ 'den daha az fleksiyon kontraktürü olması

- Patello femoral eklem osteoartritinin olmaması

- $20^{\circ}$ 'den daha fazla düzeltme gerektirmeyen genu varum olguları

- Vücut kitle indeksinin 25'in altında olması

Yüksek tibial osteotomi (YTO) eksternal fiksatörünün avantajları şu şekilde sıralanabilir:

- Proksimal ark (8), karbon fiber esaslı olup titanyum esaslı ek bileşenler nedeniyle oldukça hafiftir (ağıllık kulIanılan shanz vidalarının (18) sayısına göre değissmekle birlikte yaklaşık 400-450 gr arasında değişmektedir).

- Menteşe noktasının (20) osteotomi hattının lateralde uzandığı korteksle frontal planda aynı iz düşüme sahip olması nedeniyle lateral kortekse hasar vermeksizin distraksiyonun gerçekleşmesi sağlanır.

- Kesi bloğu (5) üzerinde $10^{\circ}$ 'lik posterior eğim sayesinde tibial eğim ayarının kendiliğinden yapılabilmesi sağlanır (istenildiğinde kesi bloğu (5) hareketleri ile eğim ayarı değiştirilebilir).

- Proksimal ve distalde shanz tutucular $(4,7)$ üzerinden farklı açılarda ve konfigürasyonlarda shanz vidası (18) gönderebilme olanağı bulunmaktadır.

- Distraktör (6) yardımılla sistem üzerinde ayarlama yapabilme olană̆ı bulunur.

Diğer implantlara (plak, U çivisi vb.) üstünlük sağlayabilecek noktaları şu şekilde sıralanabilir:

- Ameliyat sonrası alçı-atel uygulaması gerektirmemektedir.

- Ameliyat sonrası hastaya hemen yük verdirebilme olanağı bulunmaktadır.

- Fiksatörün, ameliyat içerisinde lateral korteks hasarı, plato uzanımlı kırık varlığında bile erken aktif hareket ve tam yük verdirmeye uygun olan stabil bir yapısı vardır. 
- Cerrahi girişim için küçük bir cilt insizyonu yapılmaktadır. Bu şekilde büyük kesiler oluşturulmasına gerek kalmamaktadir.

- Ameliyat sonrası erken dönemde grafi kontrolüne göre düzeltme miktarında değiş̧iklik yapma imkânı bulunmaktadır.

- YTO eksternal fiksatörünün çıkartılması için ikinci bir cerrahi girişime (ve anestezi uygulamasına) gereksinim duyulmamaktadır."

İstemler ${ }^{[1]}$

"1. Buluş, YTO cerrahisinde kullanılan fiksatörler ile ilgili olup, özelliği;

- bacağı her iki taraftan kavrayan en az bir hizalayıcı (1),

- hizalayıa (1) ile irtibatlanan en az bir açılanabilir bağlantı parçası (3) ve/veya proksimal ark (8),

- proksimal ark (8) üzerinde en az bir proksimal shanz tutucu (7),

- açılanabilir bağlantı parçası (3) alt kısmında en az bir distal shanz tutucu (4),

- proksimal ark (8) üzerine monte, de-monte edilen, cilt üzerinde açılacak kesinin konumunu ve boyutunu ayarlamayı sağlayan en az bir kesi bloğu (5),

- açılanabilir bağlantı parçası (3) ile irtibatlı en az bir fibula başı hizalayıcı aparat (2),

- düzeltme açısının ayarlanıp kontrol edildiği en az bir açısal gösterge (19) içeren YTO eksternal fiksatörü ile karakterize edilir.

2. Istem 1'e uygun YTO eksternal fiksatörü olup, özelliği; prosksimal ark (8) ile açılanabilir bağlantı parçası (3) arasında en az bir teleskobik rod (6) içermesidir.
3. Yukarıdaki istemlerden herhangi birine uygun YTO eksternal fiksatörü olup, özelliği; proksimal shanz tutucu (7) ve distal shanz tutucu (4) üzerinde en az bir shanz vidası yuvası (21) içermesidir.

4. İstem 1'e uygun YTO eksternal fiksatörü olup, özelliği; kesi bloğu (5) üzerinde, açılı konumda en az bir kesi açıklı̆ğ (23) ve/veya Kirschner teli yuvası (22) içermesidir.

5. İstem 1'e uygun YTO eksternal fiksatörü olup, özelliği; açılanabilir bağlantı parçalarının (3) uç kısmında açısal düzeltme konumunun ayarlanmasını sağlayan en az bir menteşe noktası (20) içermesidir.

6. İstem 1'e uygun YTO eksternal fiksatörü olup, özelliği; lateral kortekse hasar vermeksizin distraksiyonun gerçekleşmesini sağlamak üzere osteotomi hattının lateralde uzandığı korteksle frontal planda aynı iz düşüme sahip olan menteşe noktası (20) içermesidir.

7. İstem 1'e uygun YTO eksternal fiksatörü olup, özelliği; tibial eğim ayarının kendiliğinden yapılabilmesini săglayan kesi bloğu (5) üzerinde $10^{\circ}$ 'lik posterior eğime sahip en az bir kesi açıklığı (23) içermesidir.

8. İstem 1'e uygun YTO eksternal fiksatörü olup, özelliği; fibula başını hizalayıcı aparatı (2) oluşturan, fibula Kirschner teli yönlendirici vida (9) ile irtibatlı fibula Kirschner teli gövdesi (10), fibula Kirschner teli gövde bağlantı vidası (11) ve fibula Kirschner teli bağlantı parçası (12) içermesidir.

9. İstem 1'e uygun YTO eksternal fiksatörü olup, özelliği; proksimal shanz tutucunun (7) üzerinde hareket ederek konumunun ayarlanmasını sağlayan yuva bulunan proksimal ark (8) içermesidir.”

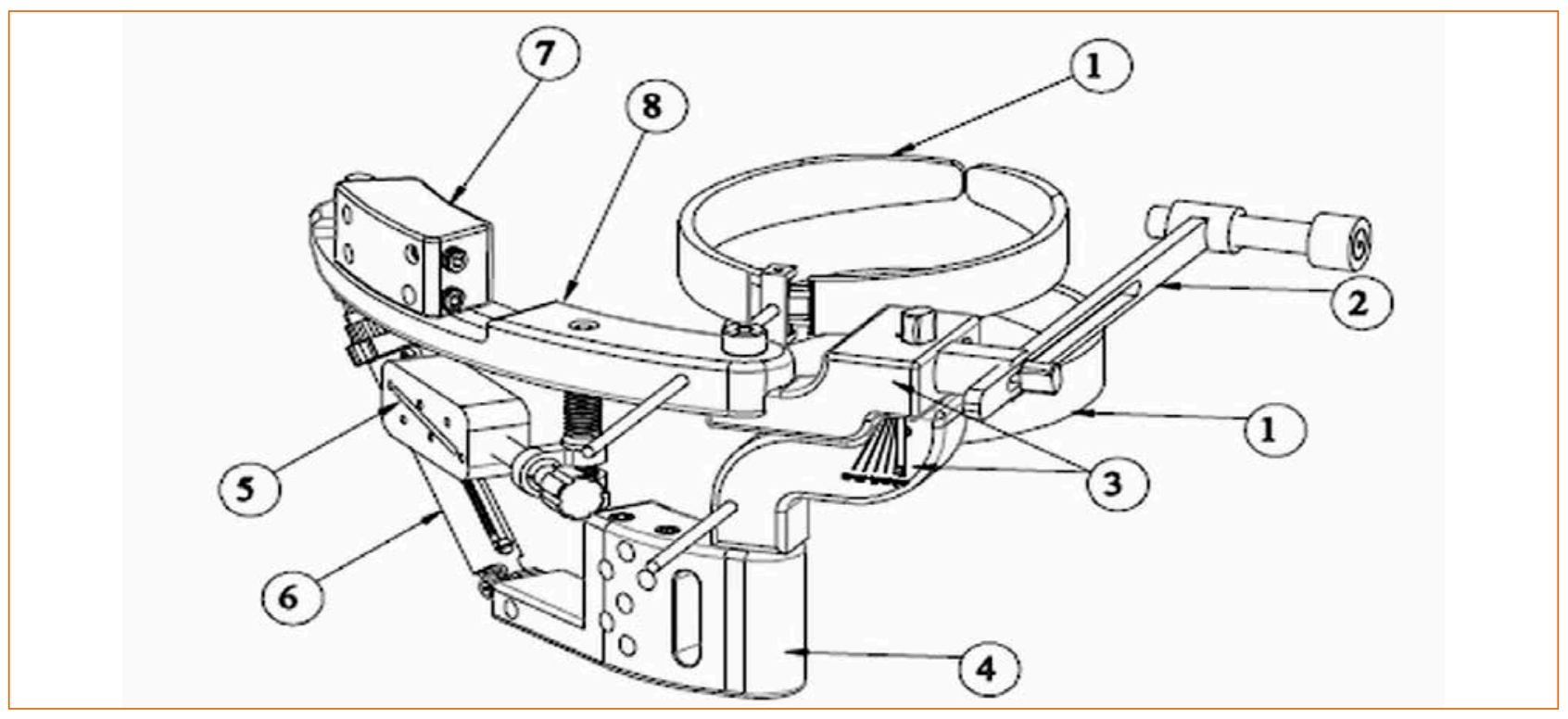

Şekil 1. Buluşun monte edilmiş halinin çizimidir. 


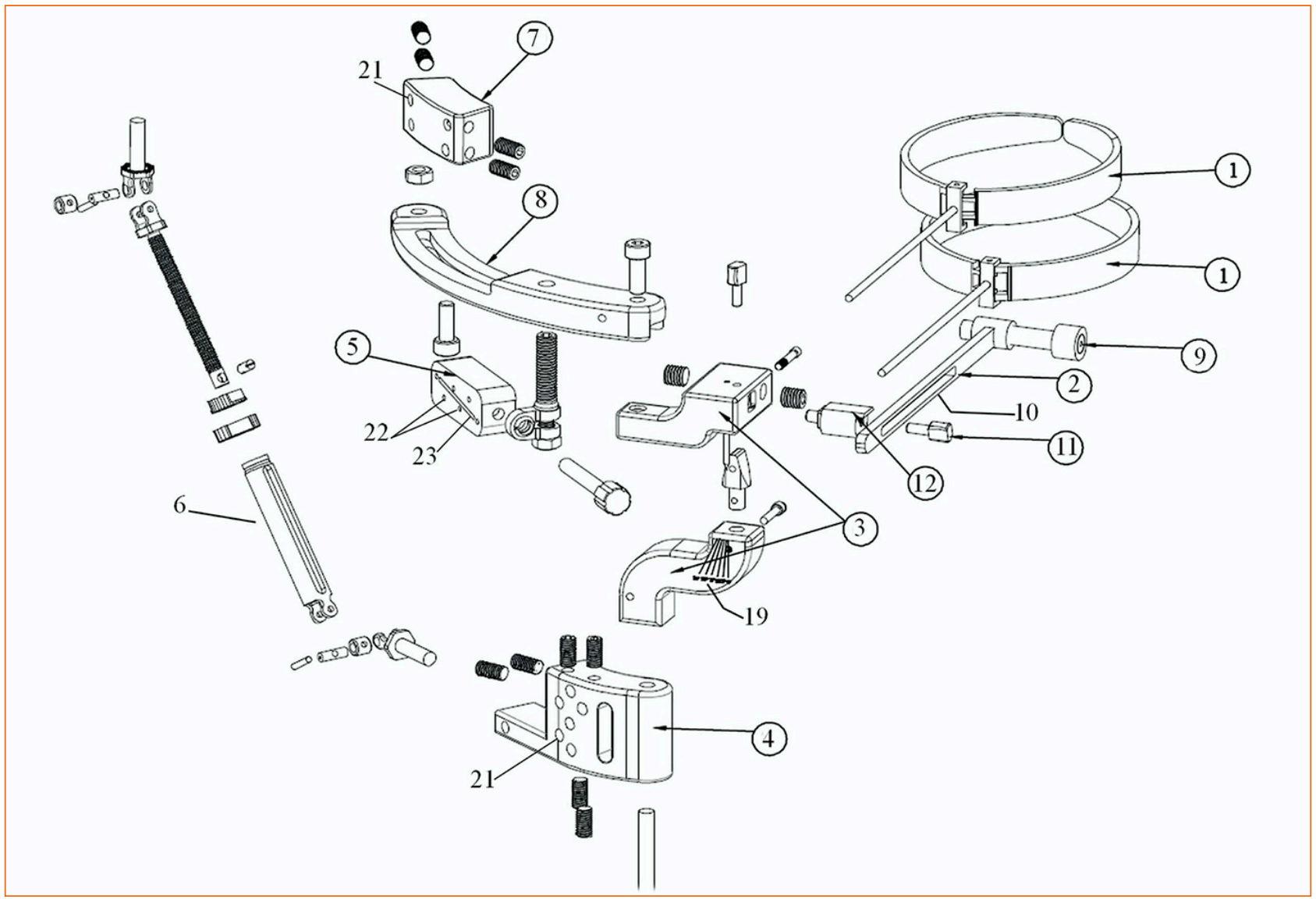

Şekil 2. Buluşun de-monte halinin çizimidir.

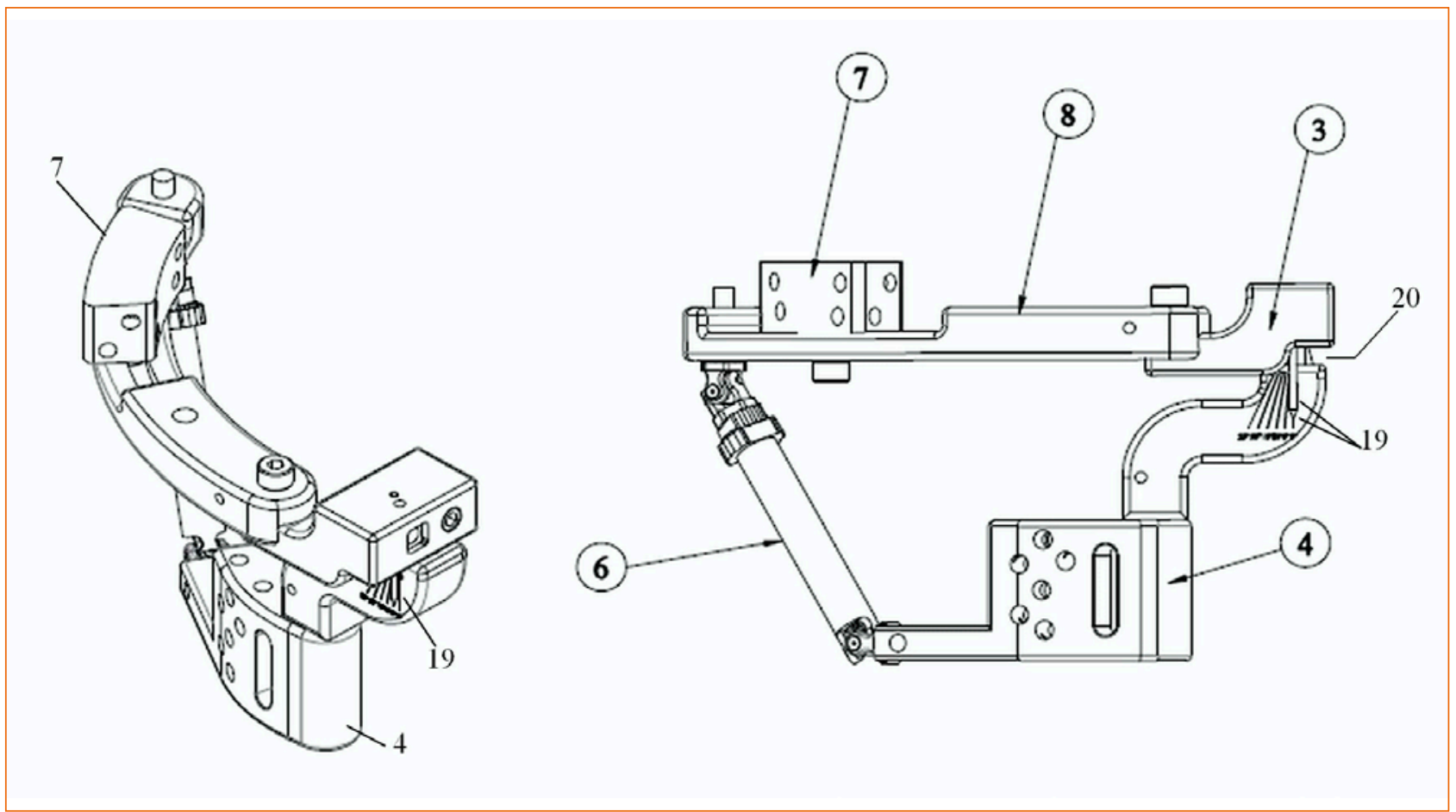

Şekil 3. Buluşun yan perspektif ve önden görünüşünün çizimidir. 


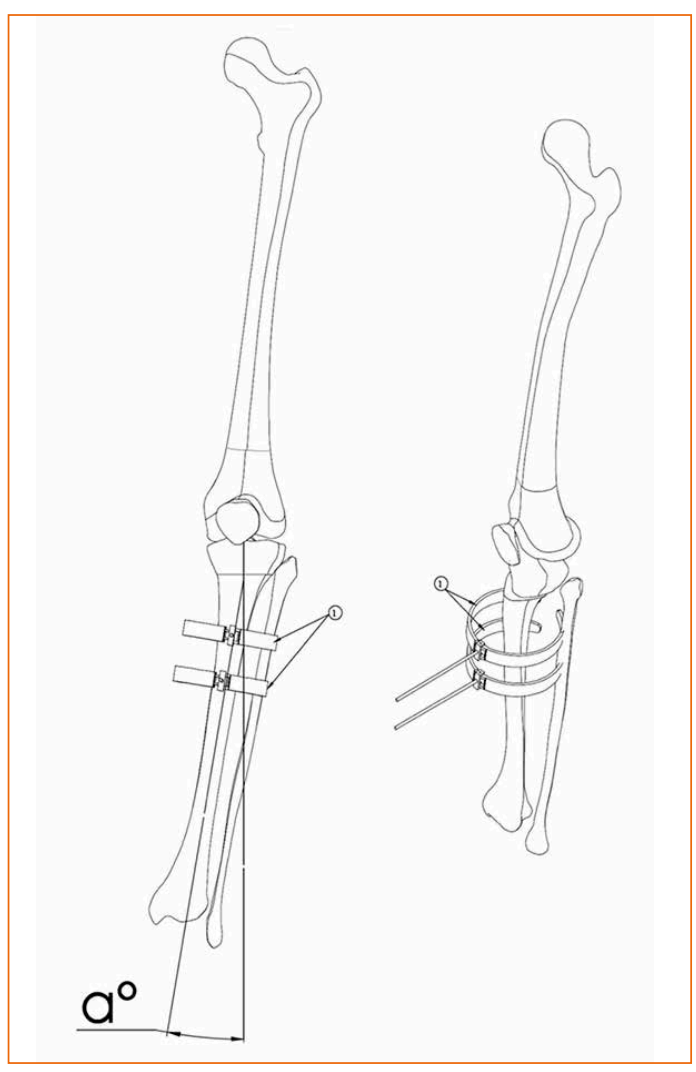

Şekil 4. Buluşun temsili bir uygulamasında sistemin tibiaya ortalanabilmesi için kullanılacak hizalayıcıların gösterildiği çizimdir.

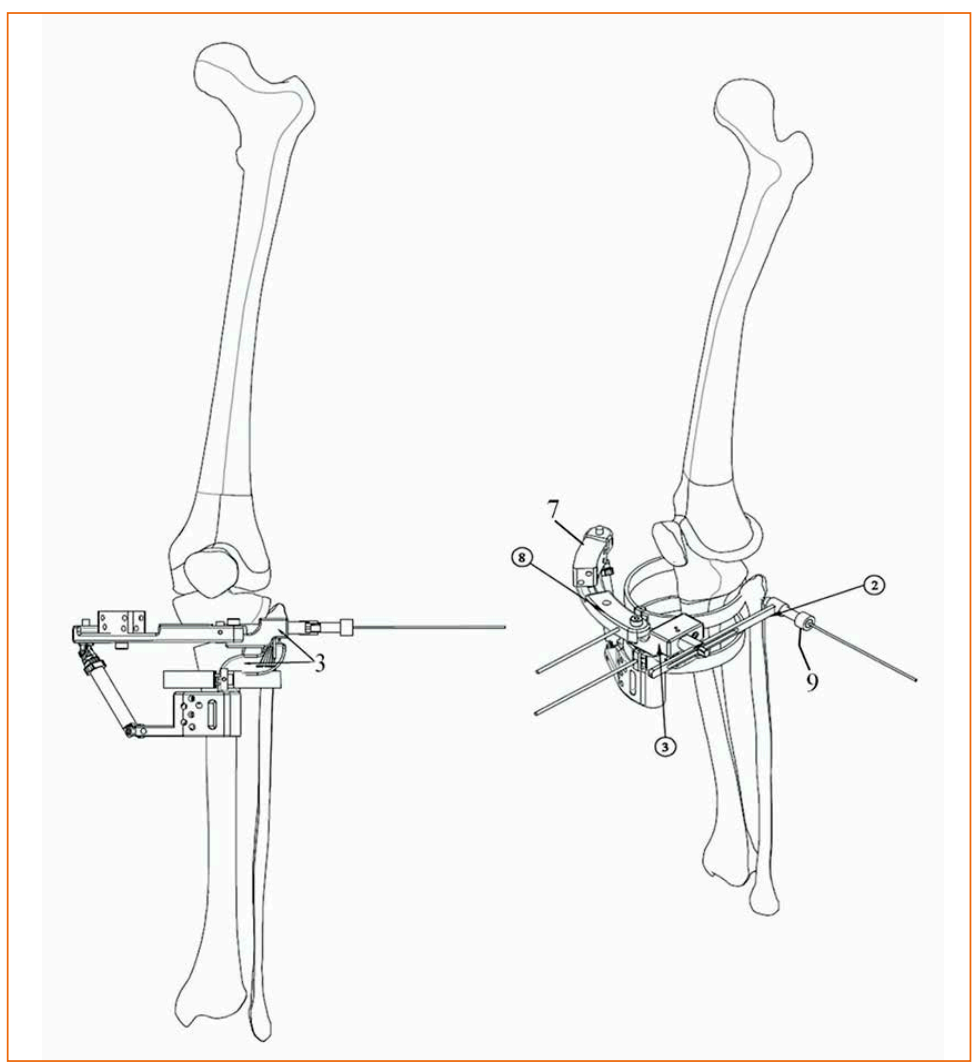

Şekil 5. Buluşun temsili bir uygulamasında eksternal fiksatör sisteminin fibula başına izdüşümlenebilmesi için kullanılan fibula başı hizalayıcı aparatın gösterildiği çizimdir.

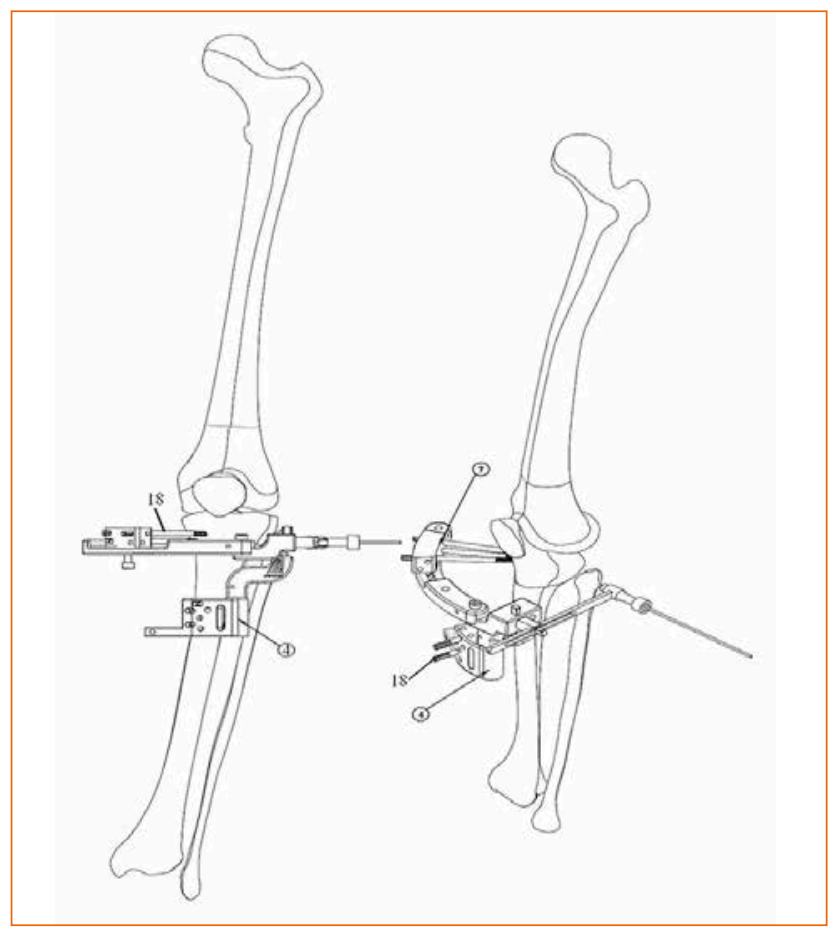

Şekil 6. Buluşun temsili bir uygulamasında eksternal fiksatörün proksimal ve distal shanz tutuculardan shanz vidaları gönderilerek tibiaya tespit edilmesini gösteren çizimdir.

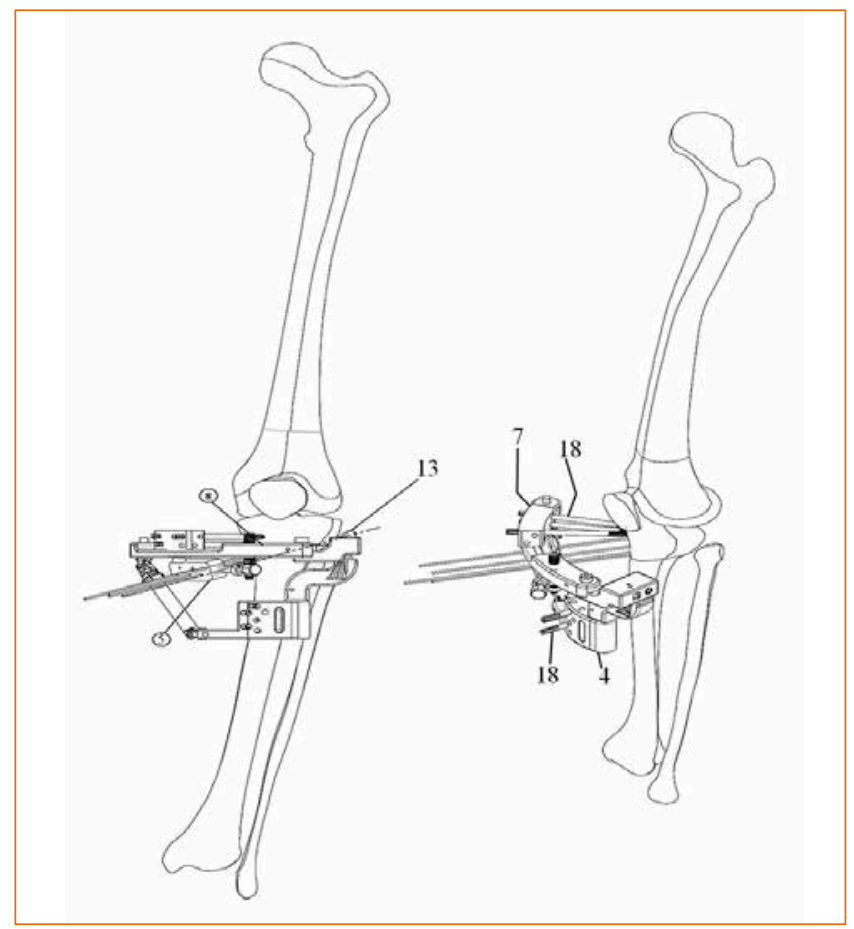

Şekil 7. Buluşun temsili bir uygulamasında kesi bloğu üzerinden fibula başına doğru Kirschner tellerinin gönderilmesini gösteren çizimdir. 


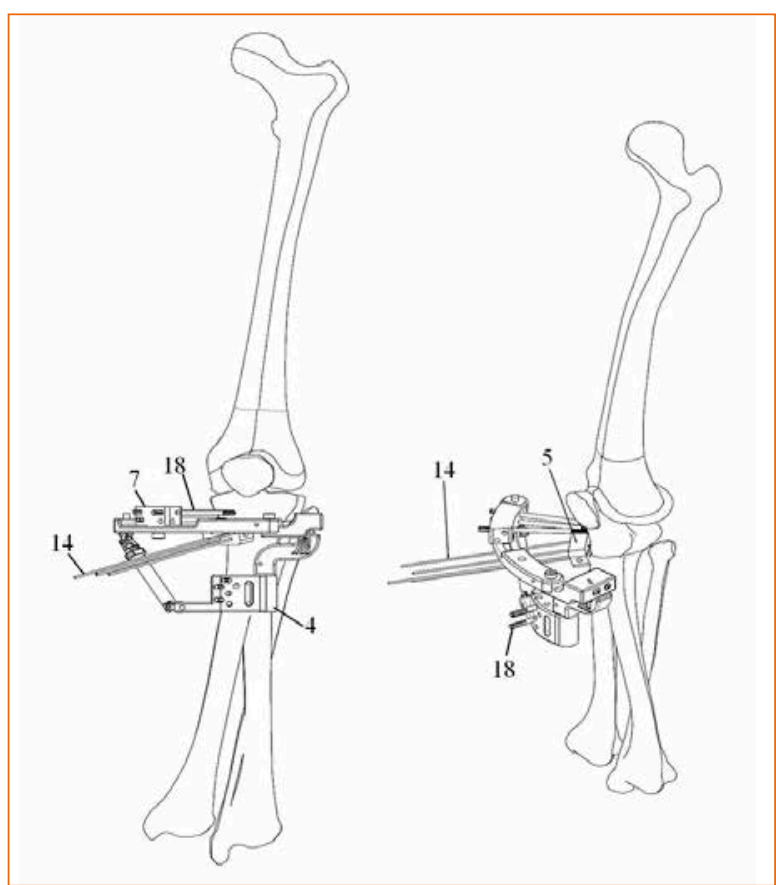

Şekil 8. Buluşun temsili bir uygulamasında kesi bloğunun Kirschner telleri üzerinden cilde doğru yaklaştırılmasını gösteren çizimdir.

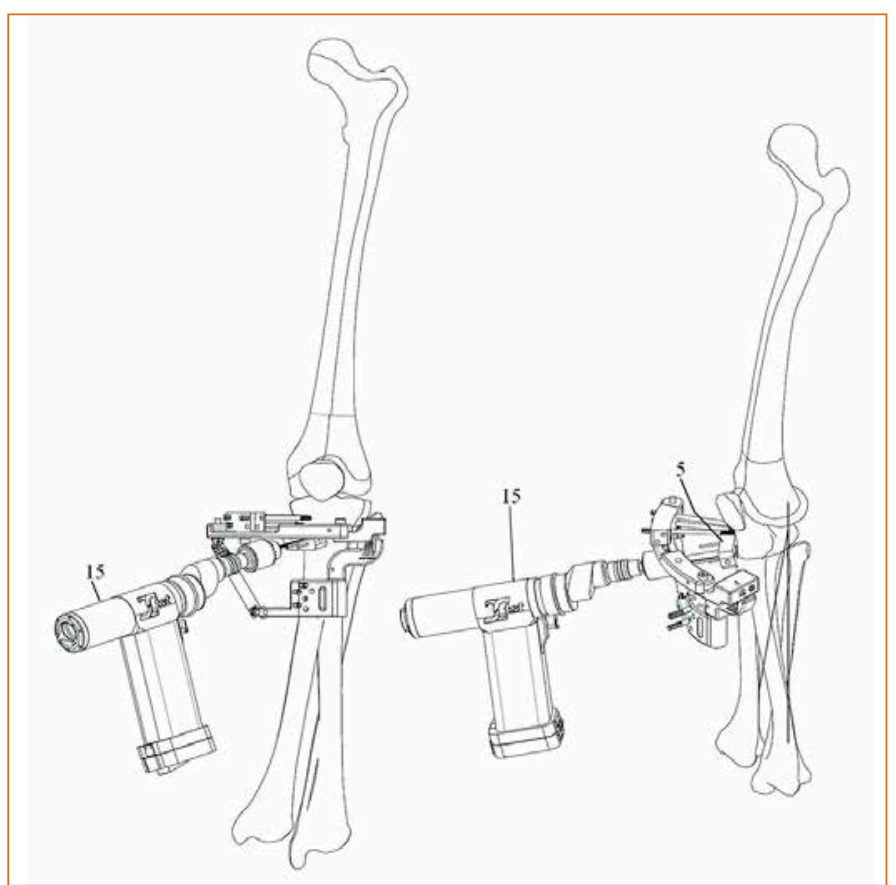

Şekil 9. Buluşun temsili bir uygulamasında motorlu testere ile kesi bloğu aracılığıyla gerçekleştirilen kemik kesisini gösteren çizimdir.

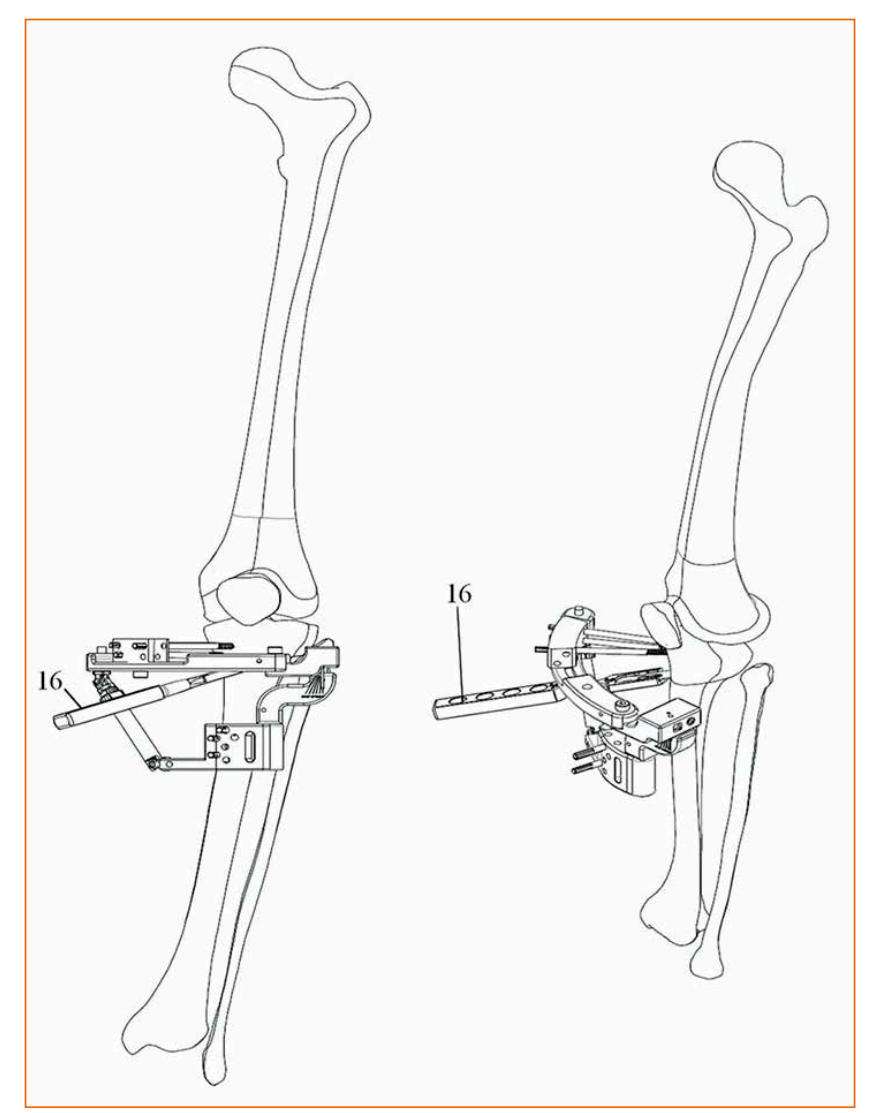

Şekil 10. Buluşun temsili bir uygulamasında manuel osteotomla gerçekleştirilen kemik kesisini gösteren çizimdir.

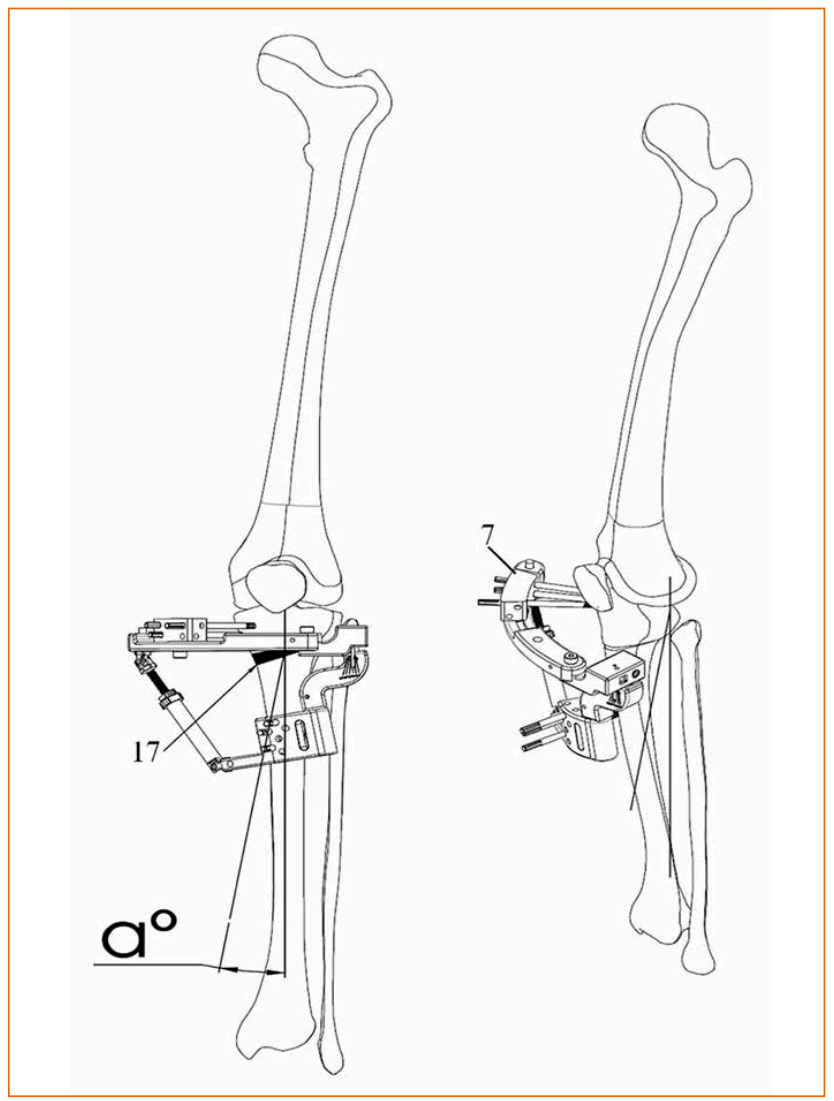

Şekil 11. Buluşun temsili bir uygulamasında osteotomi ve distraksiyon işlemi sonrası kesi aralığına greft yerleştirilmesini ve sistemin tibiaya tespit edilmiş son halini gösteren çizimdir. 


\section{YAZARIN KONUYLA ILGILI ÇALIŞMALARI/ TECRÜBELERI}

Medial açık kama YTO cerrahisinde sıklıkla plak-vida tespiti kullanılmaktadır. Ancak düzeltme miktarının ameliyat sonrası değiştirilememesi, her olguda erken aktif yüklenmeye izin verilememesi, karşı korteks ya da tibia platosuna uzanan kırık hattı varlığında tespitin yetersiz kalabilmesi gibi bir takım dezavantajlar mevcuttur. ${ }^{[10-14]}$ Eksternal fiksatörler YTO cerrahisinde ameliyat sonrası dinamik düzeltme imkânı sağlayabilen implantlardır. ${ }^{[15]}$ Geliştirdiğimiz YTO eksternal fiksatörü ile 2014 - 2016 yılları arasında ameliyat ettiğimiz ve en az 2 yıllık takiplerini gerçekleştirdiğimiz 12 hastanın (9 kadın, 3 erkek) 14 dizini klinik ve radyografik olarak değerlendirdik. ${ }^{[16]}$

Cerrahi sırasında hastaların yaş ve vücut kitle indeksi ortalamaları sırasıyla 52 yıl (dağılım 37-59) ve 26,5 $\mathrm{kg} / \mathrm{m}^{2}$ (dağılım 24-30) idi. Kellgren-Lawrence evrelemesine göre 10 dizde evre 1, 4 dizde evre 2 gonartroz mevcuttu (Şekil 12). Radyografik değerlendirmede anatomik femorotibial açı (FTA), yük taşıma çizgisinin tibia platosu üzerindeki konumu, düzeltme miktarı, patellar yükseklik (PY) ve posterior tibial eğim açısı (PTEA) ameliyat öncesi, ameliyat sonrası erken dönem ve son kontroller için kaydedildi. ${ }^{[16]}$
Tüm hastalarda YTO cerrahisi öncesi diz artroskopisi uygulandı. Eksternal fiksatör 5 mm'lik shanz çivileri ile tibia proksimaline tespit edildikten sonra, fiksatör üzerindeki kılavuz sistem aracılığıyla tibial tüberkülün proksimalinden osteotomi gerçekleştirildi. Gerekli düzeltme elde edildikten sonra osteotomi aralığı iliak kristadan alınan otogreft ve allogreft kombinasyonu ile dolduruldu (Şekil 13). Ameliyat sonrası 1. gün çekilen radyografilerde, eğer ameliyat öncesi tasarlanan düzeltme miktarına ulaşılamamışsa fiksatör üzerinden gerekli düzeltmeler gerçekleştirildi. Ameliyat sonrası kısmi yükle mobilize edilen hastalarda 3. hafta tam yükle mobilizasyona izin verildi. Klinik değerlendirmede WOMAC ve Knee Society Skorları (KSS) kullanıldı. Klinik ve radyografik sonuçların istatistiksel değerlendirmesinde IBM SPSS (Statistical Package for Social Sciences for Mac ver. 20, IBM Corp, Armonk, NY) programı kullanıldı. Tekrarlayan ölçüm karşılaştırmaları ANOVA testi ile gerçekleştirildi. İstatistiksel anlamlılık sınırı $p<0,05$ olarak kabul edildi. ${ }^{[16]}$

Ortalama takip süresi 28 ay (24-40), ortalama düzeltme miktarı $10^{\circ}$ (dağılım $7,5^{\circ}-15^{\circ}$ ) idi. Eksternal fiksatörün çıkartılma süresi ortalama 10 hafta (dağılım 8-16) idi (Şekil 14). Ameliyat sonrası 1 . günde 3 hastada eksternal fiksatör $5^{\circ}$ fazla
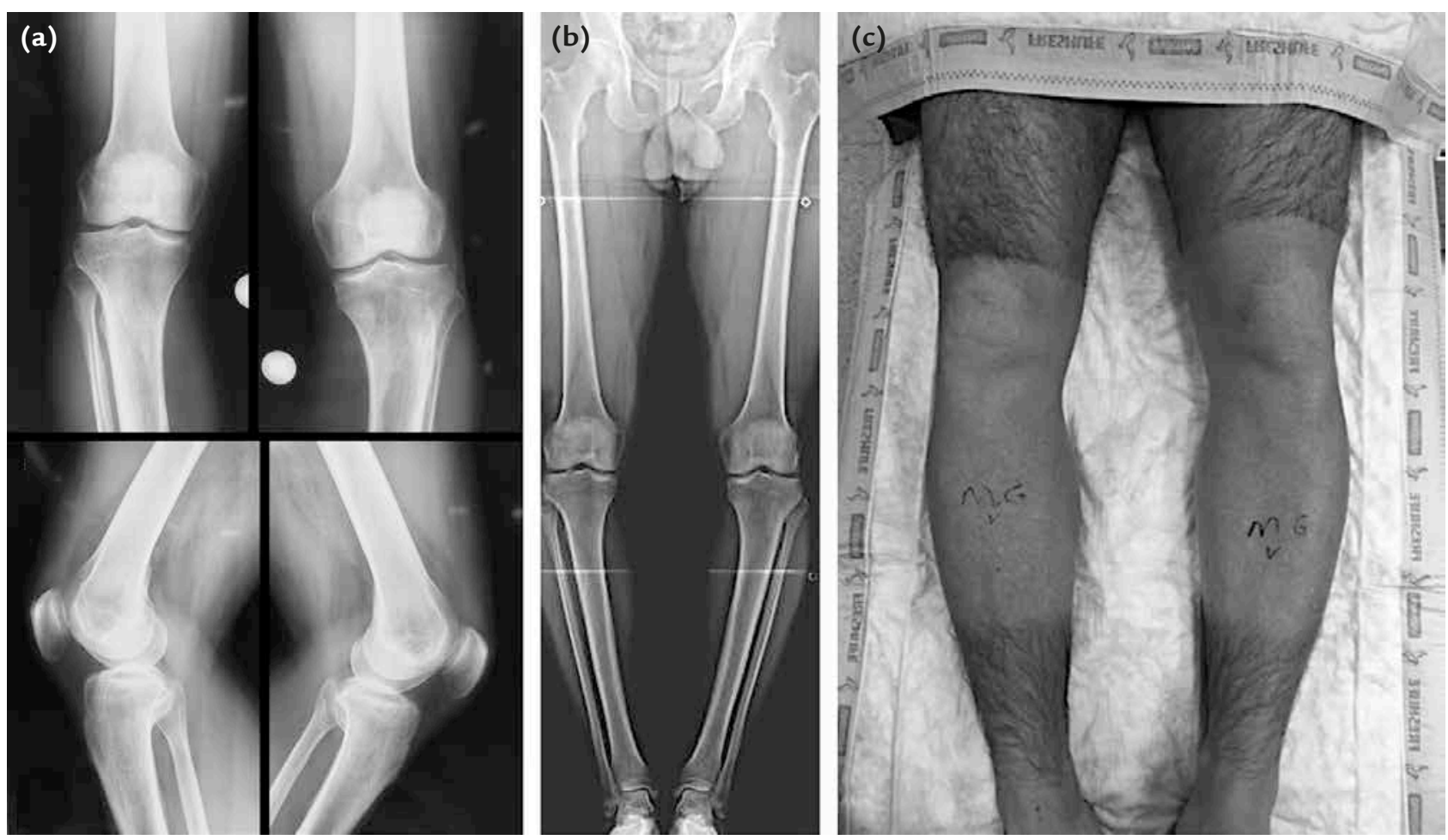

Şekil 12. a-c. Her iki dizinde genu varum deformitesi olan 48 yaşındaki erkek hastanın ameliyat öncesi ön-arka ve lateral radyografileri (a), ortoröntgenografisi (b) ve klinik görünümü (c). 

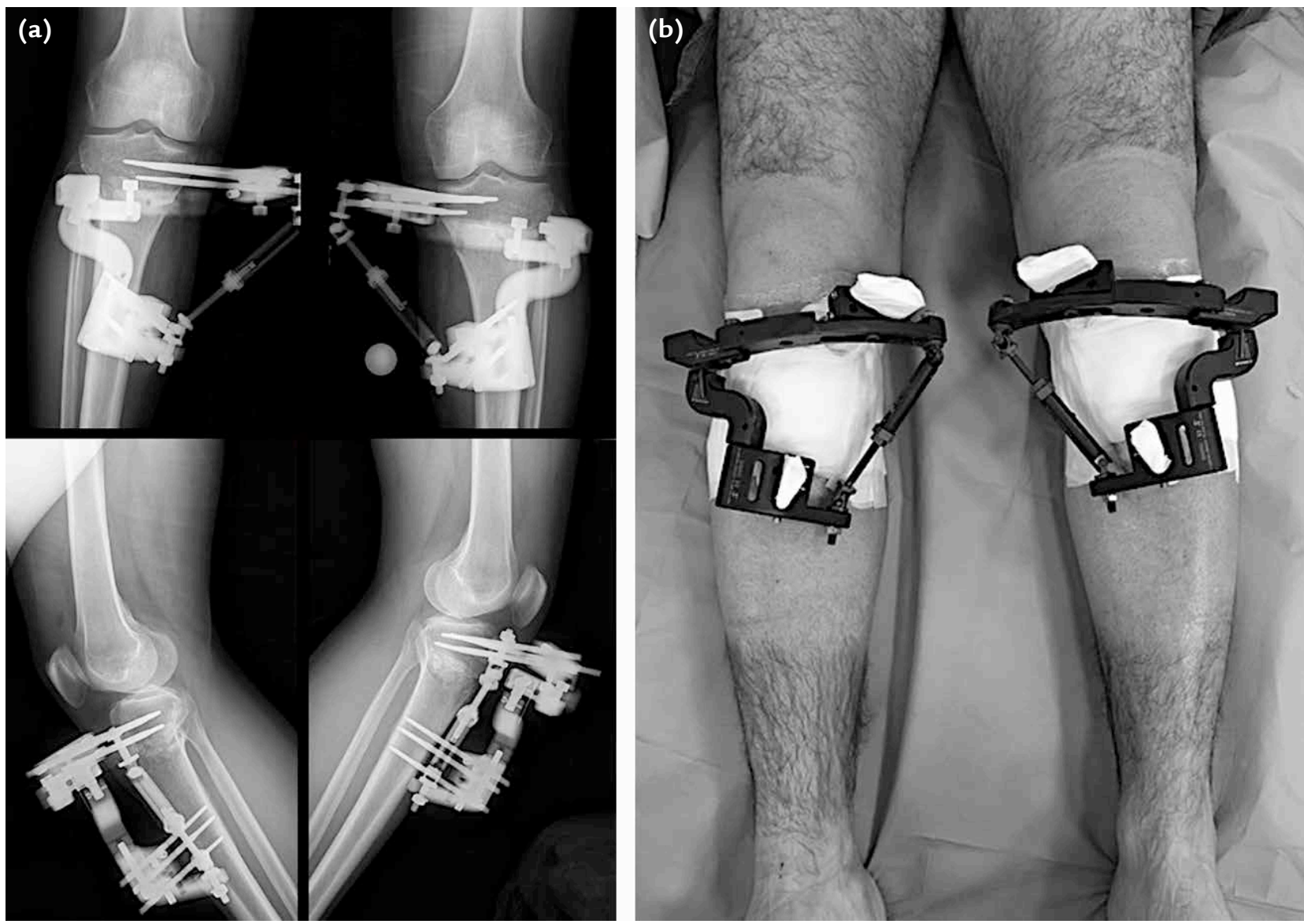

Şekil 13. a, b. Hastanın ameliyat sonrası erken dönemde ön-arka ve lateral radyografileri (a) ve klinik görünümü (b).
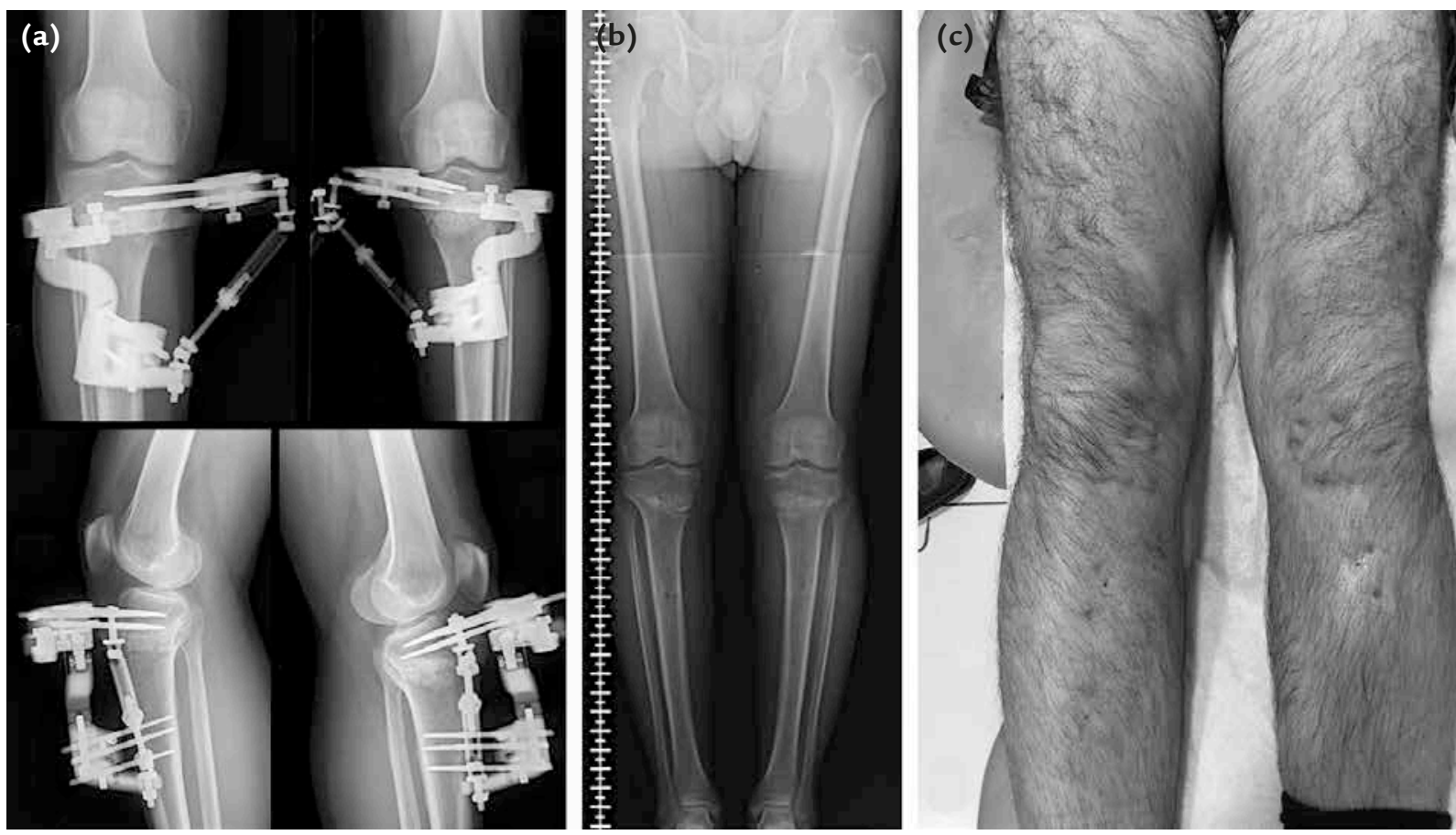

Şekil 14. a-c. Hastanın ameliyat sonrası 10. haftada ön-arka ve lateral radyografileri (a), 12. haftada çekilmiş ortoröntgenografisi (b) ve eksternal fiksatör çıkartıldıktan sonraki klinik görünümü (c). 
düzeltme işlemine tabi tutuldu. Ameliyat sonrası erken dönemde belirgin olarak düzelen $(p=0,005)$ FTA ve yük taşıma çizgisi konumunun, ameliyat sonrası erken dönem ve son kontrol değerleri arasındaki ortalama fark sırasıyla $2^{\circ} \pm 0,4^{\circ}$ ve $\% 3 \pm \% 1$ idi (Şekil 15). PY ve PTEA ameliyat sonrası istatistiksel olarak değişikliğe uğramadı $(p=0,1)$. WOMAC ve KSS skorları son kontrollerde anlamlı derecede düzeldi $(p=0,005)$ (Tablo 2). Bir hastada lokal pansuman ve antibiyotik tedavisi ile düzelen çivi yolu enfeksiyonu tespit edildi. Diğer bir hastada osteotomi hattında kaynamama nedeniyle plak-vida tespiti ile revizyon uygulandı. ${ }^{[16]}$

Medial açık kama YTO cerrahisi için özel tasarlanmış ve akut düzeltme imkânı sunan eksternal fiksatör, ameliyat sonrası düzeltme miktarında değişiklik yapma imkânı sunan, PY ve PTEA'yı etkilemeksizin güvenle kullanılabilecek bir implant seçeneğidir. ${ }^{[16]}$
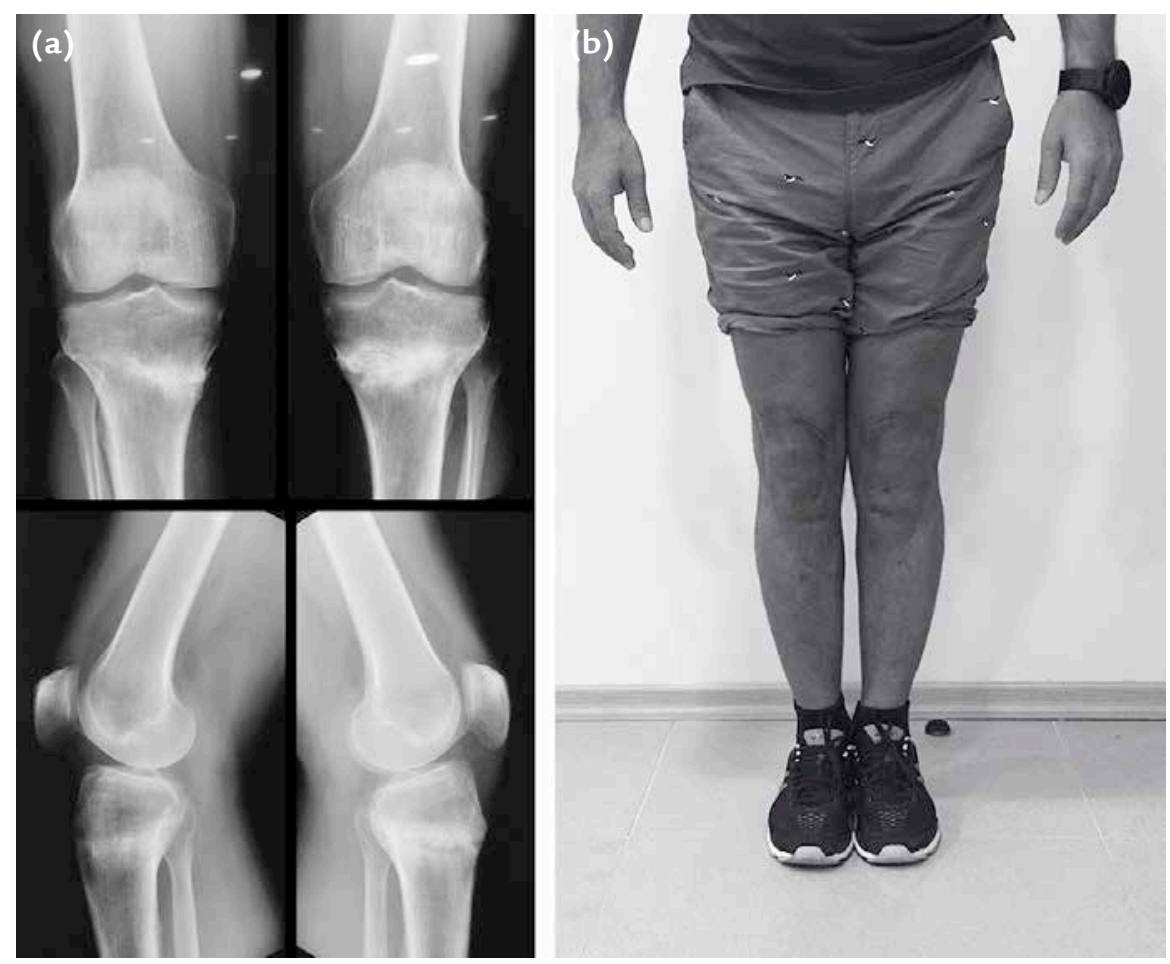

Şekil 15. a, b. Hastanın ameliyat sonrası 24. ayda çekilmiş ön-arka ve lateral radyografileri (a) ve klinik görünümü (b).

Tablo 2. Hastaların ameliyat öncesi, ameliyat sonrası erken dönem ve son takiplerde ortalama femorotibial açı (FTA), yük taşıma çizgisi yüzdesi, patellar yükseklik (PY), posterior tibial eğim açısı (PTEA), WOMAC ve Knee Society (KSS) diz skorlaması karşılaştırmaları (ortalama değerler ile birlikte \pm standart sapma ve parantez içerisinde dağılım değerleri verilmiştir) ${ }^{[16]}$

\begin{tabular}{|c|c|c|c|c|}
\hline & Ameliyat öncesi & Ameliyat sonrası erken dönem & Son takip & p değer \\
\hline FTA & $\begin{array}{l}5^{\circ} \pm 3,8^{\circ} \text { varus } \\
\left(0^{\circ}-11^{\circ} \text { varus }\right)\end{array}$ & $\begin{array}{c}4,8^{\circ} \pm 0,6^{\circ} \text { valgus } \\
\left(4^{\circ}-6^{\circ} \text { valgus }\right)\end{array}$ & $\begin{array}{c}2,8^{\circ} \pm 0,8^{\circ} \text { valgus } \\
\left(0^{\circ}-6^{\circ} \text { valgus }\right)\end{array}$ & 0,005 \\
\hline $\begin{array}{l}\text { Yük taşıma çizgisi } \\
(\%)\end{array}$ & $\begin{array}{c}16,6 \pm 12 \\
(0-38)\end{array}$ & $\begin{array}{c}55 \pm 4 \\
(48-62)\end{array}$ & $\begin{array}{c}52 \pm 3 \\
(42-60)\end{array}$ & 0,005 \\
\hline PY & $\begin{array}{c}1 \pm 0,06 \\
(0,9-1,1)\end{array}$ & $\begin{array}{l}1 \pm 0,07 \\
(1-1,2)\end{array}$ & $\begin{array}{l}1 \pm 0,09 \\
(1-1,2)\end{array}$ & 0,1 \\
\hline PTEA & $\begin{array}{c}8,6^{\circ} \pm 1,1^{\circ} \\
\left(7,3^{\circ}-10,5^{\circ}\right)\end{array}$ & $\begin{array}{l}9,2^{\circ} \pm 1,02^{\circ} \\
\left(8^{\circ}-10,8^{\circ}\right)\end{array}$ & $\begin{array}{l}9,1^{\circ} \pm 0,91^{\circ} \\
\left(8^{\circ}-10,3^{\circ}\right)\end{array}$ & 0,1 \\
\hline WOMAC & $\begin{array}{l}54,6 \pm 6,13 \\
(38,5-60)\end{array}$ & - & $\begin{array}{r}8,4 \pm 2,79 \\
(5,2-15)\end{array}$ & 0,005 \\
\hline KSS & $\begin{array}{c}66,8 \pm 2,97 \\
(62-72)\end{array}$ & - & $\begin{array}{l}88,5 \pm 4,67 \\
(78-96)\end{array}$ & 0,005 \\
\hline
\end{tabular}




\section{KAYNAKLAR}

1. Yüksek Tibial Osteotomi Eksternal Fiksatörü. T. C. Türk Patent Enstitüsü. Patent Başvuru Belgesi. No:2014/12961. https://portal.turkpatent.gov.tr/anonim/arastirma/patent/ detayli

2. High Tibial Osteotomy External Fixator. United States Patent. Patent No: US 10,307,171 B2. http://patft.uspto.gov/netacgi/ nph-Parser?Sect $1=$ PTO1\&Sect $2=$ HITOFF \&d $=$ PALL $\& p=1 \& u=\% 2 F$ ne tahtml\%2FPTO\%2Fsrchnum.htm\&r=1\&f=G\&l=50\&s1=10,307,171. PN.\&OS=PN/10,307,171\&RS=PN/10,307,171

3. Sharma L, Song J, Felson DT, Cahue S, Shamiyeh E, Dunlop DD. The role of knee alignment in disease progression and functional decline in knee osteoarthritis. JAMA 2001;286:188-95. Crossref

4. Rossi R, Bonasia DE, Amendola A. The role of high tibial osteotomy in the varus knee. J Am Acad Orthop Surg 2011;19:590-9. Crossref

5. Amis AA. Biomechanics of high tibial osteotomy. Knee Surg Sports Traumatol Arthrosc 2013;21:197-205. Crossref

6. Floerkemeier S, Staubli AE, Schroeter S, Goldhahn S, Lobenhoffer P. Outcome after high tibial open-wedge osteotomy: a retrospective evaluation of 533 patients. Knee Surg Sports Traumatol Arthrosc 2013;21:170-80. Crossref

7. Brouwer RW, Bierma-Zeinstra SMA, van Raaij TM, Verhaar JAN. Osteotomy for medial compartment arthritis of the knee using a closing wedge or an opening wedge controlled by a Puddu plate. J Bone Joint Surg Br 2006;88-B:1454-9. Crossref

8. Coventry MB, Ilstrup DM, Wallrichs SL. Proximal tibial osteotomy: a clinical long-term study of 87 cases. J Bone Joint Surg Am 1993;75:196-201. Crossref
9. Lobenhoffer P, Agneskirchner JD. Improvements in surgical technique of valgus high tibial osteotomy. Knee Surg Sports Traumatol Arthrosc 2003;11:132-8. Crossref

10. Song EK, Seon JK, Park SJ. The complications of high tibial osteotomy: closing-versus opening-wedge methods. J Bone Joint Surg Br 2010;92-B:1245-52. Crossref

11. Miller BS, Downie B, McDonough EB, Wojtys EM. Complications after medial opening wedge high tibial osteotomy. Arthroscopy 2009;25:639-46. Crossref

12. van Raaij TM, Brouwer RW, de Vlieger R, Reijman M, Verhaar JA. Opposite cortical fracture in high tibial osteotomy: lateral closing compared to the medial opening-wedge technique. Acta Orthopaedica 2008;79:508-14. Crossref

13. Takeuchi R, Ishikama $H$, Kumagai K, Yamaguchi $Y$, Chiba N, Akamatsu Y, Saito T. Fractures around the lateral cortical hinge after a medial opening-wedge high tibial osteotomy: A new classification of lateral hinge fracture. Arthroscopy 2012;28:85-94. Crossref

14. Lee SC, Kim SJ, Jung KA, Choi DH, Hwang BY. An early sign of intraarticular fracture of the lateral tibial plateau during opening wedge high tibial osteotomy. Knee 2013;20:66-8. Crossref

15. Gillooly JJ, Tilkenidis K, Simonis RB, Monsell F. The treatment of high tibial osteotomy non-union with the Ilizarov external fixator. Strat Traum Limb Recon 2012;7:93-7. Crossref

16. Güven M, Kadıoğlu B, Bildik C, Akman B, Yüksel K, Özkan NK. Medial açık kama yüksel tibial osteotomi cerrahisinde eksternal fiksatör alternatifi. XXVIII. Ulusal Türk Ortopedi ve Travmatoloji Kongresi, Belek-Antalya. Acta Orthop Traumatol Turc 2018:52(Suppl 1):95. https://www.aott.org. tr/Content/files/sayilar/665/AOTT_52_S1.pdf 